\title{
Planting seeds for an improved agrifood system? Linking the aims of the alternative agrifood movement to executive action in the first two years of the Obama administration
}

\author{
K. Michelle Glowa, ${ }^{\text {a }}$ Sarah Carvill, ${ }^{\text {a }}$ and Costanza Rampini ${ }^{a}$
}

Submitted 1 September 2010 / Accepted 28 April 2011 / Published online 26 May 2011

Citation: Glowa, K. M., Carvill, S., \& Rampini, C. (2011). Planting seeds for an improved agrifood system? Linking the aims of the alternative agrifood movement to executive action in the first two years of the Obama administration. Journal of Agriculture, Food Systems, and Community Development, 1(3), 31-52. http://dx.doi.org/10.5304/jafscd.2011.013.009

Copyright (C) 2011 by New Leaf Associates, Inc.

\begin{abstract}
This paper uses several case studies to look at the dialogic relationship between the Obama administration and the alternative agrifood movement. We evaluate the case studies based on criteria developed from the agroecology literature and literature on food security, agrarianism, and the alternative agrifood movement as a whole. Additionally we compare the policy tools utilized and the funding levels of each of the cases. Our findings suggest that the Obama administration is committed to tackling issues of food security and promoting the well-being of small- and mid-scale farmers and their local agrifood economies. Deconsolidation of large agribusiness, equitable trade, and workers' rights do not appear to be high priorities on Obama's food and agriculture agenda,
\end{abstract}

\footnotetext{
* Corresponding author: K. Michelle Glowa, University of California, Santa Cruz, 1156 High Street, Santa Cruz, CA 95064 USA; +1-301-908-0641; kglowa@ucsc.edu

a Department of Environmental Studies, University of California, Santa Cruz, USA
}

however. Our analysis further indicates that the administration views agriculture and food policy as embedded into a broader socioeconomic and political system. Both the administration and the alternative agrifood movement support the use of capacity-building, symbolic, and incentive tools that emphasize community and individual responsibility. Overall, there is evidence that the alternative agrifood movement and the Obama administration are co-constructing a more community-based food system that simultaneously reflects neoliberal rationale.

\section{Keywords}

agroecology, alternative food systems, executive politics, neoliberal governance, Obama administration, policy tools, social movement

\section{Introduction}

Days before his historic election to the presidency, Senator Barack Obama told Time magazine political commentator Joe Klein, "Our agriculture sector actually is contributing more greenhouse gases than our transportation sector. And in the mean time, 
it's creating monocultures that are vulnerable to national security threats...sky-high food prices or crashes in food prices, huge swings in commodity prices, and are partly responsible for the explosion in our healthcare costs" (Klein, 2008, "The Full Obama Interview," para. 45). Following a campaign famous for its rhetoric about hope and change, Obama's articulation of the profound reverberations of mainstream American agriculture gave adherents of the nation's diverse alternative agrifood movement reason for optimism. Shortly thereafter, however, Obama appointed two strong proponents of genetically modified crops, Tom Vilsack and Roger Beachy, to key positions at the U.S. Department of Agriculture (USDA). Since opposition to genetically modified organisms has often been a component of movement activism, these initial actions left many alternative food system advocates wondering what type of "change" could be expected of this new administration.

This paper analyzes Obama's agricultural agenda and policy-making by systemically evaluating early initiatives and appointments by the Obama administration, as well as the policy tools and funding associated with them. This evaluation is complemented by a review of the reactions of the alternative agrifood movement to these programs and appointments. We ask how the alternative agrifood movement has defined its priorities, how the administration has responded to the movement in terms of policy initiatives, and how the movement has reacted. Finally, we consider the overall direction of change coproduced by the administration and alternative agrifood movement.

We begin by briefly describing the rise of an alternative agrifood movement in the United States and its important characteristics and tenets. Subsequently, we analyze several key food- and agriculture-related actions from the administration's first two years in office in an effort to understand Obama's commitment to the alternative agrifood movement and his popularity within that movement. To do this, we draw on literature in the social and natural sciences, including agroecological research and social studies of alternative agrifood movements, to develop a set of evaluative criteria that encompass movement goals and priorities. We apply these criteria to three USDA programs, three projects championed by first lady Michelle Obama, and three appointments related to food and agriculture. This criteria-based analysis reveals the extent to which early policy initiatives in the Obama administration align with and diverge from goals of the alternative agrifood movement. Because the programs and appointments we analyze are not equivalent, we also examine the policy tools they deploy and program funding to place the criteriabased analysis in context.

\section{Background}

The Alternative Agrifood Movement in the U.S. In the United States, there exists a diverse group of food- and agriculture-focused activists united by a suite of shared goals. Social scientists have used Scott's (1990) framework to define these actors as a social movement (e.g., Allen, 2004; Hassanein, 2003). As Allen summarizes, a social movement "is a collective actor constituted by individuals who understand themselves to have common interests and identity, and who act collectively in an attempt to change widespread existing political, economic, and cultural conditions" (2004, p. 5).

Today's alternative agrifood movement has its roots in a variety of other social movements, many with long histories in the United States and internationally, including the populist, environmental, antihunger, labor, and civil rights movements (Allen, 2004; Constance, 2009; Hassanein, 2003). The various subgroups within the alternative agrifood movement together have articulated a critique of the dominant agriculture and food system as a corporate-controlled, technologybased, monocultural, export-oriented system that negatively affects public health, food quality and nourishment, traditional livelihoods, indigenous and local cultures, and the environment. They advocate for a transition to more decentralized, democratic, cooperative, and independent organic farming systems, based on the principles of diversity, synergy, and recycling (Allen, 2004; Petrini \& Lionette, 2007). 
Food and Agriculture in the Obama Campaign

Obama's campaign materials reflect awareness of the connections between agriculture and the environment, and claim that locally oriented systems of agricultural production benefit communities (Obama for America, 2008). The campaign's rural policy statement characterizes consolidation in the agricultural sector as one of two key problems facing rural communities (Organizing for America, 2008). These initiatives directly reflect the alternative agrifood movement's preference for decentralized production and independent local economies (cf. Allen, 2004). However, the policy prescriptions represent relatively conservative reforms, and at times campaign materials conflate "organic" with "sustainable" in recommending policy changes intended to support the latter (Heffernan, Hendrickson, \& Gronski, 1999; Obama for America, 2008; Shames, 2009). The campaign's rural policy statement also supports an increased role for biofuels, including corn ethanol, in U.S. agriculture and energy policy; promoting corn as fuel is unlikely to bolster diversified farms. Both the rhetoric and the proposed policies emphasize helping small growers "compete on the open market" rather than challenging agribusiness directly.

\section{Movement Response}

In October 2008 the New York Times published a "food issue" of its magazine section featuring an extensive letter to the next president by author and movement spokesperson Michael Pollan. Pollan enumerates the failures of today's agrifood system and asserts that the incoming president must recognize the role that it plays in shaping other priority issues, such as health and energy independence (Pollan, 2008). Days before Pollan's article appeared in the Times, Jim Goodman, a policy fellow at the Institute for Agriculture and Trade, wrote of the need for candidates Obama and McCain to "talk real farm policy," but credited Obama with going beyond the failed policies of Reagan, Clinton, and Bush (Goodman, 2008, p. 1). $\mathrm{He}$ also called on adherents of the alternative agrifood movement to be active in demanding policy action after the inauguration.
Following the election, the Organic Consumers Association "celebrated a hard fought and welldeserved victory," but maintained that the next step was to pressure the Obama administration to take action to improve the national food system within its 100 first days in office (Organic Consumers Association, 2008, p. 1). In December 2008, the U.S. Working Group on the Food Crisis addressed the president-elect in a letter calling for the development of "a democratic and just food policy" and the appointment of persons with similar commitments to positions in several areas of the new administration (U.S. Working Group, 2008 , p. 2). Overall, the movement was engaging optimistically with the president-elect, reflecting hope that the arrival of the Obama administration would bring change in the agrifood system.

\section{Methods}

In order to systematically analyze the Obama administration's emergent food and agriculture agenda in relation to the alternative agrifood movement, we reviewed social science studies of the movement and the agroecology literature. We used these literatures to develop a set of evaluative criteria reflective of the movement's aims and emphases, and applied these criteria to six agriculture-related policy actions and three appointments of the Obama administration. We then examined the funding levels and policy tools associated with the six selected policy actions.

\section{Case Selection}

In selecting cases, we were guided by a set of indicators of presidential performance on environmental policy developed by Vig (2010). His taxonomy identifies the types of actions that are most reflective of the influence of a president, as opposed to Congress or other political actors. Examples include agenda, budget proposals, executive orders, and appointments.

Our cases clustered into three categories: USDA programs, initiatives spearheaded by the first lady, and appointments. Although the first lady is not an elected or appointed official in the administration, political scientists have noted the importance of her political role (O’Connor, Nye, \& van 
Assendelft, 1996). The functions of the first lady have increased from ceremonial to that of advisor to the president and political agenda-setter. Michelle Obama champions issues surrounding food and diet both in the policy arena and by promoting healthier cultural practices such as urban gardening.

We acknowledge that these nine cases are not equally significant and, consequently, not equally reflective of administration priorities. To account for these differences, we also compare funding and the design of the six policy initiatives. The titles of the appointees indicate their relative power; we consider these differences for our criteria-based analysis in the discussion.

\section{Source Material and Data}

Our data are drawn primarily from three types of source materials. To analyze proposed and incipient policy initiatives, we relied on government press releases, official program websites, speeches from program launches, and news coverage in mainstream national publications from the start of the administration to the end of 2010. In order to gain insight into appointees' backgrounds, we analyzed public remarks, interviews, editorials, and speeches, as well as the published materials and curricula vitae of appointees from academia and, for appointees from the government sector, voting records and position statements compiled by nonpartisan government accountability clearinghouses such as WhoRunsGov.com and Project Vote Smart. Finally, we utilized editorial material, press releases, memos, blog posts, reader comments, and other statements culled from blogs and websites identified with the alternative agrifood movement. The accessibility of blogs helps account for the movement's large and vocal web presence, which also includes professional websites of major nonprofit organizations.

\section{Analysis and Evaluation}

The design of our study was inspired by Layzer's (2008) assessment of ecosystem-based management (EBM) efforts. Layzer evaluates a series of EBM initiatives to understand whether management plans (outputs) have measurably improved environmental conditions (outcomes). In the case of the Obama administration, it is still too early to analyze outcomes; changes to the agrifood system itself that can be linked directly to administration policy initiatives. Instead, we focus here on outputs, evaluating whether the specified objectives of the administration's new programs and the stated opinions of its appointees are consistent with the critique formulated by the alternative agrifood movement. In order to do this, we rated each case with a "Yes" or "No" for each criterion. A program (or appointee) received a "yes" when we found evidence that it (or she or he) was likely to contribute to the realization of movement goals and values encompassed by the criterion in question. A "no" finding, therefore, does not mean that a program would undermine movement objectives; it means that we did not find evidence indicating that the program or appointee would perform positively against the criterion in question.

Given the highly qualitative nature of our data, a quantitative weighting system seemed likely to result in arbitrary values. We therefore evaluated the relative importance of each of the six policy initiatives by comparing its budgets and the policy tools it employs. A program's budget is one indicator of the level of impact it is likely to have; policy tools tell us what policymakers assume is needed to promote desired behaviors in a specific arena (Schneider \& Ingram, 1990).

Schneider and Ingram (1990) define policy tools as the instruments used by public policy to induce the changes needed to achieve policy goals. They identify five categories of policy tools according to their underlying motivational strategies.

- Authority tools are based on the assumption that directives from government officials will change the behavior of agency employees or the public.

- Incentive tools use tangible rewards and punishments to prompt specific behaviors.

- Capacity-building tools provide target populations with information and 
resources deemed necessary to achieve the target policy goals.

- Symbolic and hortatory tools appeal to cultural values and beliefs in order to stimulate policy-related actions.

- Learning tools involve the participation of target populations in the decisionmaking process through hearings, boards and panels.

An understanding of the policy tools mobilized by the administration supplements our analysis by emphasizing how the administration translates commitment into policy action (Schneider \& Ingram, 1990).

\section{Limitations}

Our analysis reflects the alternative agrifood movement's views as constrained by the rhetorical situations through which we accessed them and the particular individuals and organizations who chose to comment in broadly accessible formats, such as press releases and blog posts. Our discussion of movement responses may therefore reflect a bias toward the subset of the movement that utilizes these spaces.

Our analysis of appointments focused on appointees' professional experiences prior to joining the administration. After they are nominated, appointees communicate with the public as spokespersons for their administrations. This confounds efforts to analyze postappointment public comments by appointees as evidence of appointees' individual views, experiences, and qualities - the very things that form the basis for nominations and make the appointment of a particular individual an "indicator" of an administration's performance in a given policy area. This problem forced us to rely more heavily on preappointment data to evaluate appointees. Some appointees' relevant prior work, however, was in the private sector or the rank and file of government agencies, resulting in a paucity of preappointment data.

Volume 1, Issue 3 / Winter 2010-2011

\section{Evaluative Criteria}

In order to methodically analyze Obama's policies and nominations, we developed 12 criteria intended to reflect the major goals of the alternative agrifood movement in the United States (table 1). Our criteria, while sometimes overlapping, are grouped into two broad categories: environmental soundness and social critique.

\section{Environmental Soundness}

Our criteria for assessing the agroecological basis of Obama's policies and appointments are based on the agroecology literature. Many current definitions of agroecology as a discipline extend its focus beyond individual farms to local and global food systems and emphasize a systems perspective that includes social, ecological, and economic factors, although some agroecologists still focus on natural science (Wezel \& Soldat, 2009). We use the systems definitions of agroecology provided by Altieri (2002) and Gliessman (n.d.) to distill generalized criteria for assessing policy that may support the development of agroecology in U.S. farming systems. According to Gliessman (n.d.), "sustainable agroecological systems maintain their natural resource base, rely on minimum artificial inputs from outside the farm system, manage pests and diseases through internal regulating mechanisms, [and] recover from the disturbances caused by cultivation and harvest" (Gliessman, n.d., bullets). Altieri (2002) concurs with Gliessman in identifying key processes that should be promoted in agroecosystems (see also Warner, 2007). Based on these definitions, we developed criteria 1 through 6 for evaluating policies and appointments by the Obama administration.

\section{Social Critique}

The social critique of conventional food production advanced by the alternative movement is also broad, encompassing issues as diverse as farm economics, human rights, and food safety. Constance (2009) identifies the movement's agrarian question as the set of emphases that focus on "the relationship between structure of agriculture and quality of life for farmers and rural communities" (p. 5) that began to garner attention in the early 1980s, when plummeting prices led to a 
"farm crisis" in the rural U.S. (see also Associated Press, 1985; Hansen, 2003; Kline, 1981). From this "agrarian" critique, we can trace the development of three emphases of the modern alternative agrifood movement: Regaining political and economic control over a conventional food system that is dominated by a small number of corporations with transnational reach; increasing the prices small growers receive for their products on the market, both internationally and domestically; and encouraging the implementation of policies that foster place-based agrifood economies. These emphases are the bases for criteria 7, 8, and 10 .

Constance (2009) also describes an "emancipatory" thread linking the agrifood system to human rights concerns. Central to the emancipatory question is the critique of the uneven distribution of poverty, hunger, and food insecurity among different groups of people in the United States (Allen, 2004).
Among the issues emphasized under this umbrella are food security, farm workers' rights and conditions, food quality (specifically nutrition), and food safety. These concerns formed the bases of criteria 9 and 11 in our evaluative scheme. We also include the importance of energy independence in the list of concerns associated with "social critique" (criterion 12). As Obama himself has noted, agriculture in the United States is a major source of greenhouse gas emissions due to its use of fossil fuels for various stages of the production and distribution process (Klein, 2008).

\section{Case Studies}

\section{USD A Programs and Initiatives}

We analyzed three USDA programs: The Healthy Food Financing Initiative (HFFI), Know Your Farmer, Know Your Food (KYF2), and the People's Garden Initiative.

\section{Table 1. Criteria for Evaluating Case Studies}

\section{Environmental Soundness}

Does the case study or key actor support objectives that are consistent with those prescribed by agroecology?

1. Does it take a systems approach to considering ecological, social, and economic factors within the same piece of policy?

2. Does it address agroecological issues on multiple physical scales?

3. Does it support the improvement of soil health, fertility, and biological activity?

4. Does it promote natural control mechanisms available internal to the agroecosystem?

5. Does it emphasize resource conservation and maintenance of the resources in any given system?

6. Does it encourage the enrichment of biodiversity and "synergisms between components"?

\section{Social Critique}

Does the case study or key actor support objectives that are consistent with the social critique raised by the community food security movement?

7. Does it support deconsolidation of food production and processing by supporting small- and mid-scale producers and/or revising policies that confer advantages to large producers and processors?

8. Does it promote higher prices for farm products or support or incentivize the development of value-added enterprises, such as food processing and/or alternative markets for agricultural products? Does it help farmers capture a larger proportion of their products' retail value?

9. Does it promote access to cheap, nutritious, and culturally appropriate food by targeting the distribution, quality and price accessibility of food, the underlying causes of hunger and food insecurity (e.g, poverty, illiteracy and unemployment)?

10. Does it promote the overall vitality of the local agrifood economy?

11. Does it reflect a general concern for the well-being of farm workers, food processing workers, and food service workers?

12. Does it promote energy independence within the agrifood sector by reducing food miles and promoting the use of renewable energy? 
HFFI is a joint effort by the USDA, the Department of Health and Human Services (HHS), and the Department of the Treasury intended to provide access to affordable and nutritious food in all areas of the United States. Partner agencies have committed to funding loans, grants, and tax credits for private and nonprofit initiatives that bring supermarkets to communities lacking fresh food. Other projects eligible for HFFI support include farmers' markets and refrigerated produce cases for convenience stores (HHS, 2010). HFFI provides incentive for food retailers to open stores, and increases the capacity of retailers and community groups to act in cases where private capital is reluctant to finance projects. The initiative is based on a well regarded public-private partnership, the Pennsylvania Fresh Food Financing Initiative (Brown, 2010; PolicyLink, 2010a; Reinvestment Fund, 2007). HFFI was announced in February 2010 by the Obama administration as a US $\$ 400$ million commitment. Legislation to establish and fund HFFI was introduced in the Senate and the House on November 30, 2010, with funding at the US $\$ 500$ million level (HHS, 2010; U.S. Congress, 2010b; U.S. Congress, 2010c).

Know Your Farmer, Know Your Food (KYF2), chaired by USDA Deputy Secretary Kathleen Merrigan, is a communication mechanism used by the USDA to promote the distribution of money already authorized by Congress (Ferguson, 2010). In a telephone conversation with the authors in January 2011, staff at the office of Deputy Secretary Merrigan revealed that the initiative has no dedicated funds; nevertheless, it has been at the forefront of the USDA and Merrigan's outreach effort for the past two years (Luke Knowles, personal communication, January 13, 2011). KYF2 publicizes loans, grants, technology transfers, and other incentives that support local farmers, strengthen rural communities, promote healthy eating, and protect natural resources (USDA, 2009a). The majority of the opportunities publicized through KYF2 are intended to launch farm-to-school programs and encourage a largescale conversion of farmers to certified organic farming. KYF2 functions as a symbolic tool: It repackages existing incentive programs to further encourage the participation of small-scale farmers and producers by using language that signals an increased commitment to local and sustainable agriculture. The initiative also serves as a capacitybuilding tool that connects small producers with resources intended to foster agroecological practices and the vitality of local farming economies. In the last year, a blog was launched on the KYF2 website to provide real-world examples of the activities it is coordinating across the country (USDA, 2010a).

The People's Garden Initiative (PGI) challenges USDA employees to start "people's gardens" at USDA facilities or help communities create gardens. At the USDA's headquarters in Washington, DC, a garden of over 600 square feet has been started, and future plans include on-site composting, rain gardens ${ }^{1}$, a pollinator garden, and use of organic and sustainable techniques. The initiative also promotes education through trainings and print resources. The initiative uses incentives, capacity-building, and symbolic tools. The headquarters garden is intended as a model to demonstrate the potential of gardens on both federal and private land. It is also a symbol of the administration's commitment to environmental sustainability and community food security. The program builds capacity by educating communities across the United States in garden development. In a telephone conversation with the authors, a USDA staff member explained that each field office uses funds from existing budgets along with volunteers and donations to run its program (Livia Marques, personal communication, January 14, 2011). In addition to educational opportunities, in 2010 a People's Garden School Pilot Program grant competition was developed, budgeted for US $\$ 1$ million, to incentivize school garden development. With the exception of the salary of the PGI director, which was paid by the USDA, support for

\footnotetext{
${ }^{1}$ A rain garden, according to the Rain Garden Network, is " a shallow depression that is planted with deep-rooted native plants and grasses...to capture rainwater runoff and stop the water from reaching the sewer system" (Rain Garden Network, What is a Rain Garden? Retrieved from http://www.raingardennetwork.com/ ).
} 
the headquarters' garden comes from donations and the labor of the maintenance staff and volunteers.

\section{First Lady Michelle Obama's Projects}

Three policy actions that we analyzed — Let's Move!, the Food Environment Atlas, and the White House Garden — are projects of first lady Michelle Obama.

Let's Move!, Michelle Obama's most comprehensive policy initiative, is a suite of programs intended to reduce childhood obesity in the United States by addressing its underlying causes (Obama, 2010). One of the aims of the initiative, increasing access to healthy, affordable food, overlaps with the goals of the alternative agrifood movement (Obama, 2010; USDA, 2010c). Under the banner of Let's Move!, executive-branch agencies provide new web tools and labeling programs, increase funding for existing relevant programs, and partner with the private sector to develop healthier products (USDA, 2010c). While the tools in the Let's Move! portfolio are largely capacity-building, the program also includes incentives for schools and the use of government authority (e.g., directing the Food and Drug Administration to develop new labels for food products). The public-sector programs are funded by the US $\$ 4.5$ billion Healthy, Hunger-Free Kids Act of 2010, signed in December 2010 (U.S. Congress, 2010a). The initiative also uses strategies characteristic of symbolic and hortatory tools: It relies on voluntary action by private-sector groups, and it uses promotional materials to connect the obesity-reduction goal to other major national interests, such as national security and reducing health-care costs (Obama, 2010). Additionally, public-service announcements and even the slogan "Let's Move!" are examples of a "persuasive communication strategy" similar to the "Just Say No" campaign cited by Schneider and Ingram (1990, p. 520).

The Food Environment Atlas is a project especially created for Michelle Obama's Let's Move! campaign by the USDA's Economic Research Service. It aims to "assemble statistics on food environment indicators to stimulate research on the determinants of food choices and diet quality and to provide a spatial overview of a community's ability to access healthy food and its success in doing so" (USDA, 2010b, "Objectives of the atlas," para. 4). The atlas uses 90 indicators within three categories of food environment factors: food choices, health and well-being, and community characteristics. The Food Environment Atlas is a capacity-building tool. The atlas provides information to the public that has been compiled from public, academic, and private institutions. The project aims encourage research and educate the greater public as to the conditions of their communities. It is assumed that individual free agents and "target groups will have sufficient incentive or motivation" to take action to improve their community's food environment (Schneider \& Ingram, 1990, p. 518). According to USDA staff there is no allocated budget for this program; staff from ERS are assigned to work on the atlas as needed (Vince Breneman, personal communication, January 14, 2011).

The White House Garden on the South Lawn is the first of its kind since Eleanor Roosevelt's Victory Garden in 1943 (Burros, 2009). The groundbreaking of the White House Garden in fall 2009 cost a total of US $\$ 200$ (Muir \& Wright, 2009; Office of the First Lady, 2009). Overseen by White House chef Sam Kass, the garden hosts weekly educational tours for children in Washington, DC, and provides organically grown food for the White House and a local homeless kitchen (Lee, 2009). The garden combines capacity-building tools (e.g., educational tours) with symbolic tools: the first lady's adoption of urban gardening signals that the administration is committed to values and practices advocated by the alternative agrifood movement. Since spring 2009, an additional 400 sq. ft. have been added to the garden (Kass, 2010). The garden was also featured on the popular Food Network show Iron Chef (Associated Press, 2010; Muir \& Wright, 2009).

\section{Appointments}

We analyzed three Obama administration appointments: Secretary of Agriculture Tom Vilsack, Deputy Secretary Kathleen Merrigan, and National 
Institute of Food and Agriculture (NIFA) Director Roger Beachy. ${ }^{2}$ Vilsack began his political career in municipal government in Iowa, then moved on to the Iowa state senate and, beginning in 1998, the Iowa governorship. He ran briefly for president in 2008 before giving his support to Hillary Clinton and then Obama (AllGov, 2009). Merrigan held a position as assistant professor and director of the Agriculture, Food and Environment program at Tufts University prior to her appointment, and published articles on farm-to-school nutritional programs, animal health and welfare, and organic farming standards (Lockeretz \& Merrigan, 2006; Merrigan, 2005; Merrigan \& Bailey, 2008). She is considered one of the authors of the 1990 Organic Foods Production Act, which set federal organic standards (Marlowe, 2010). Beachy has had a long career in academia and research focused on agricultural biotechnology. He is credited with early advances in genetically modified food-crop engineering (Donald Danforth Plant Science Center, 2010; Waltz, 2010).

\section{Results}

\section{USD A Programs and Initiatives}

\section{The Healtby Food Financing Initiative}

The goal of HFFI is to increase access to healthy food by providing communities with fresh food available through retail establishments (criterion 9). HFFI promotes a local agrifood economy (criterion 10) by funding community development corporations and because eligible communities are defined at the neighborhood scale. News releases emphasize the connection between food access and community "revitalization," characterizing HFFI as a "place-based approach" to food security (HHS, 2010; USDA, 2010e). The initiative does not address environmental soundness (criteria 1-6), consolidation in the food systems (criterion 7),

2 As of 20 May 2011, Roger Beachy has resigned as director of NIFA. During his short term with the USDA, Beachy oversaw the transformation of the Cooperative State Research, Education and Extension Service (CSREES) into NIFA. The search for a new director has begun (Stokstad, 2011). equitable trade (criterion 8), workers' rights (criterion 11), or energy independence (criterion 12).

HFFI was developed in cooperation with the Food Trust, an advocacy group that played an integral role in the design and implementation of Pennsylvania's FFFI (PolicyLink, 2010b), and food security activists have responded enthusiastically to the initiative (Community Food Security Coalition, 2010a; DeForest, 2010). The National Sustainable Agriculture Coalition expressed support for the initiative, but also drew attention to HFFI's narrow focus, noting, "We...hope it will be firmly linked with regional food system and rural development objectives in addition to food access" (Witteman, 2010).

\section{Know Your Farmer, Know Your Food}

The KYF2 initiative advertises financial and programmatic resources available for small-, mid-scale, and "socially disadvantaged" farmers, as well as nonprofit organizations and businesses in rural areas (criteria 7 and 10). Additionally, a large portion of the program's outreach is dedicated to farm-to-school programs (criterion 9). Although as a communication device KYF2 does not specifically promote sustainable practices, several of the programs publicized through the initiative encourage the conservation and protection of agricultural lands and the conversion to organic farming (criteria 3 and 5). KYF2 does not promote or fund any programs aimed at addressing issues related to food workers' rights and conditions (criterion 11).

The alternative agrifood community has welcomed the initiative as a new commitment to local and regional food systems on the part of the Obama administration (Jenkins, 2009). Some praise KYF2 for helping create a food-literate population that will make better choices when it comes to nutritious and local food (Kohan, 2009a). Critics point out that KYF2 does not make any real attempts to challenge the status quo of the existing agrifood system, and suggest that its support for local agrifood economies will have relatively few impacts in light of the huge federal subsidies promoting con- 
ventional large-scale agribusiness (Estabrook, 2009).

\section{The People's Garden Initiative}

This initiative focuses on education, healthy eating, community building, and the promotion of environmental sustainability, showing a truly systematic approach (criterion 1). The program is designed to promote garden creation across the country (criterion 2). The sustainable practices promoted by the garden (e.g., the pollinator garden, rainwater capture and recycling, on-site composting, organic certification, and companion planting) meet criteria 3-6. The vegetables grown in the main garden go to a local food bank (criterion 9). The initiative actively supports a local food economy (criterion 10) by promoting the farmers' market held next to the garden and by buying transplants from a local farmer cooperative. The initiative does not address criteria 7,8 , and 11 .

The initial response from bloggers to PGI was to question the legitimacy of the garden and project. It was called "lip service" to the movement - a publicity stunt with "no budget, no staff, and no real plan" (Orton, 2009, "'Secretary of Agrispinculture," para. 3). As the project developed, responses have been more positive. The Obama Foodorama blog calls it a "green fever dream [turned] to rapid reality" (Kohan, 2009b, "The People's Garden," headline). Original initiative director Valerie Frances called the project "unbelievably exciting" and other employees in the USDA "are now feeling much freer to speak up, just because of the garden" (Kohan 2009b, "The People's Garden," para. 18).

\section{First Lady Michelle Obama's Projects}

\section{Let's Move!}

Let's Move! is primarily a public health campaign that overlaps with the alternative agrifood movement on one key concern: increasing access to "healthy, affordable food" (USDA, 2010c) (criterion 9). Commitments to fund the Farm to School program and increase funding to existing farmers' market support programs may enhance local agrifood economies (criterion 10). However, the initiative's emphasis on public-private partnerships and voluntary agreements with major foodindustry actors make it unlikely that Let's Move! will challenge corporate concentration in this sector (criterion 7). The initiative does not address the environmental impacts of food production (criteria 1-6), equitable trade (criterion 8), workers' rights (criterion 11), or energy independence (criterion 12).

The movement has taken note of Michelle Obama's interest in childhood obesity. The Community Food Security Coalition characterizes it as an opportunity to further related programs such as Farm to School (Community Food Security Coalition, 2010b). The National Sustainable Agriculture Coalition commented on the strong showing by proponents of small-scale and local agriculture at the Let's Move! launch (National Sustainable Agriculture Coalition, 2010a). However, Let's Move!'s embrace of the private sector has engendered some skepticism among movement commentators. One reader of NSAC's blog complained, "Childhood obesity will not be conquered with 'co-operation from the companies that collectively provide $20 \%$ of the nation's school lunch programs', alone" (Stockwell, 2010, “One response to 'Let's Move," para. 1).

\section{The Food Environment Atlas}

The Food Environment Atlas focuses on economic and social indicators to address health food access and issues of health and nutrition. The visual description is compiled through census and other data sources that are collected at the county, state, and national levels, providing a multiscale perspective (criterion 2). Production is briefly introduced by identifying direct-sale farms, farmers' markets, and grocery stores in the context of examining food security (criteria 9 and 10). Although farm production is addressed, the atlas does not address its environmental sustainability (criteria 1 and 3-6). The project does not speak to other parts of the food system, including those represented by criteria $7,8,11$, and 12 .

Some movement organizations are enthusiastic about the atlas, describing it as "ambitious" 
(Kohan, 2010a, "Mapping Food Access,” para. 2) and "a great way to begin to look at the various disparities that exist in our country when it comes to what we eat" (Lohan, 2010, "A Food Atlas Like," para. 7). The Farmers Market Coalition (2010) website discusses the multiple ways that movement organizations, farmers, and food retailers can use the atlas to "identify market opportunities, secure community support, leverage financial resources, and more" (Farmers Market Coalition, 2010, "Using the USDA's," para. 3). At the same time, the San Francisco Bay Guardian's food-focused blog points out that the atlas functions to give "a broader comparative perspective of the food-related socioeconomic issues of the U.S." but fails to pick up on smaller physical scale problems, citing the example that, although some parts of Oakland clearly lack healthy accessible food, the map uses county-level data and therefore paints a rosy picture (Johnson, 2010, "Uproot," para. 3).

\section{The White House Garden}

The White House Garden stresses the importance of soil health, natural control mechanisms, biodiversity, and synergisms (criteria 3, 4, and 6) through a variety of practices, including the use of 55 varieties of crops, hoop houses, compost, ladybugs, mantises, and pollinators. Additionally, the seedlings for the garden are grown in the White House greenhouses and the food is distributed strictly locally (criterion 12). Finally, the educational component of the White House Garden attempts to link environmental sustainability with questions of access and nutrition (criterion 9). Overall, the White House Garden initiative focuses on the environmental critique of agriculture as formulated by the alternative agrifood movement; it does not address workers' rights and conditions, foster the vitality of the local agrifood economy, nor advocate for the conservation of natural resources beyond the farm (criteria 5, 10, and 11).

Over 110,000 people signed the Kitchen Gardeners International's "Eat the View" campaign petition started in February 2008, asking the Obama family to replant a White House Victory Garden and reserve part of the produce for local food pantries (Doiron, 2010). The groundbreaking for the White House Garden was therefore perceived as a victory for the alternative agrifood movement. Shortly after the garden's establishment, an association representing pesticide and fertilizer companies expressed uneasiness with the alternative practices of the White House Garden in a letter to Michelle Obama (McCarvel \& Braun, 2009; Taylor, 2009). Praised by foodies such as Michael Pollan as an important symbolic gesture, the garden sends a strong signal that the administration is engaging with the alternative agrifood movement (Pollan, 2008).

\section{Appointments}

\section{Tom Vilsack}

Vilsack received a "yes" on Criteria 5 (resource conservation) based on his track record as governor of Iowa. During that time, Iowa "led the nation in enrollment of acreage in the federal Conservation Reserve Program" (Project Vote Smart, 2008, "Title: Energy and Environmental Record," para. 4). Since taking office, Vilsack has vocally supported the promotion of community food security and has taken action to more closely connect food entitlement programs (e.g., WIC and SNAP) to farmers' markets (National Sustainable Agriculture Coalition, 2010b) (criterion 9). Vilsack also supports maintaining farmers on the land and in their communities (criterion 10), calls for achieving energy independence (USDA, 2009b) (criterion 12), and has made addressing civil rights concerns within the USDA a top priority since entering office (Thompson, 2010). His administration is addressing concerns from Black, Hispanic, and women farmers who have been unfairly denied farm loans, thereby addressing agricultural system workers' rights (criterion 11). We found no statements or policy actions evincing support for the agricultural practices represented by criteria 3,4 , and 6 , and our research has not found any instances of Vilsack publicly challenging the consolidation of the agrifood system or the inequality in access to the share of profits that farmers receive (criteria 7 and 8).

The movement has responded to Vilsack's appointment with concern over his support for 
genetically modified organisms (GMOs), Concentrated Animal Feeding Operations (CAFOs), large agribusiness, and the use of biofuels as a sustainable alternative energy source. The Organic Consumers Association launched a "Stop Vilsack" campaign (Cummins, 2008). Today the tune of the movement has changed a little, however. David Murphy, director of Food Democracy Now!, says the new secretary's reputation as a friend to agribusiness and ethanol producers may have been overstated. Michael Pollan has said, "He's definitely sounding a different note than his predecessors" (Black, 2009a, "Vilsack: USDA Must Serve," para. 5).

\section{Kathleen Merrigan}

Merrigan received a positive evaluation for every one of our criteria, although evidence of her support for natural control mechanisms and agrifood workers' rights is only seen in her publications and previous positions. Additionally, while Merrigan positively engages both the environmental and social critique of conventional agriculture as formulated by the alternative agrifood movement, her focus is on organic farming as defined by USDA organic standards, as opposed to other conceptual definitions of organic. Merrigan is a strong advocate for farmers' markets and other mechanisms to boost local food economies (criteria 9 and 10). As the chair of KYF2, she has emphasized the important role of small- and mid-scale farmers in the local and regional food systems (criterion 7). Merrigan also acknowledges the economic and policy barriers that prevent farmers from adopting more sustainable practices, such as organic farming (criterion 1). Finally, she argues for transitioning U.S. agriculture away from its current dependency on fossil fuels (criterion 12). Overall, Merrigan's devotion to sustainable agriculture echoes each one of the main critiques of the alternative agrifood movement, making her a crucial voice at the heart of the USDA.

Merrigan's appointment was greeted with enthusiasm on the part of the alternative agrifood movement. In fact, Merrigan's name appeared on the "Sustainable Dozen List" of progressive candidates for her position compiled by the advocacy group
Food Democracy Now! and signed by people across the country (Black, 2009b). The National Sustainable Agriculture Coalition expressed its excitement to "have a lifelong supporter of family farmers and sustainable and organic agriculture working with the administration to reform US food and agriculture policy" (National Sustainable Agriculture Coalition, 2009, "Sustainable Farming Group Applauds Choice," para. 1).

\section{Roger Beachy}

Public comments by Roger Beachy reflect an awareness of the negative environmental impacts of conventional agricultural production, including the spillover effects of chemical pesticide use and the greenhouse gas emissions associated with synthetic fertilizers (Aldhous, 2009; Beachy, 1999; Waltz, 2010); they also evince a commitment to reducing hunger and poverty domestically and around the world (Waltz, 2010). His comments acknowledge only one approach to addressing environmental and social problems in the food system, however: Expanding the role of agricultural biotechnology (Aldhous, 2009; Beachy, 1999; Waltz, 2010). His curriculum vitae lists over 200 publications on transgenic crop development; his editorial and commentary papers promote transgenic crops as the key technology for mitigating negative impacts of agriculture and addressing global hunger (Beachy, 1999, 2006; Donald Danforth Plant Science Center, 2010). Beachy's focus on technology-intensive off-farm inputs for addressing food insecurity and the environmental impacts of agriculture provide no basis for positive ratings for any of our evaluative criteria.

Alternative agrifood movement response to Beachy's appointment was strongly negative; within weeks of his nomination, a coalition of movement organizations was circulating a petition asking Obama to withdraw Beachy's nomination. A Pesticide Action Network North America (PANNA) news release described Beachy's thenemployer, the Danforth Center, as "Monsanto's de facto nonprofit research arm," a characterization repeated widely in movement-linked blogs (Endelman, 2009; PANNA, 2009; Richardson, 2009). The movement's disappointment with the 


\section{Figure 1. Obama Administration Performance on Movement Criteria}

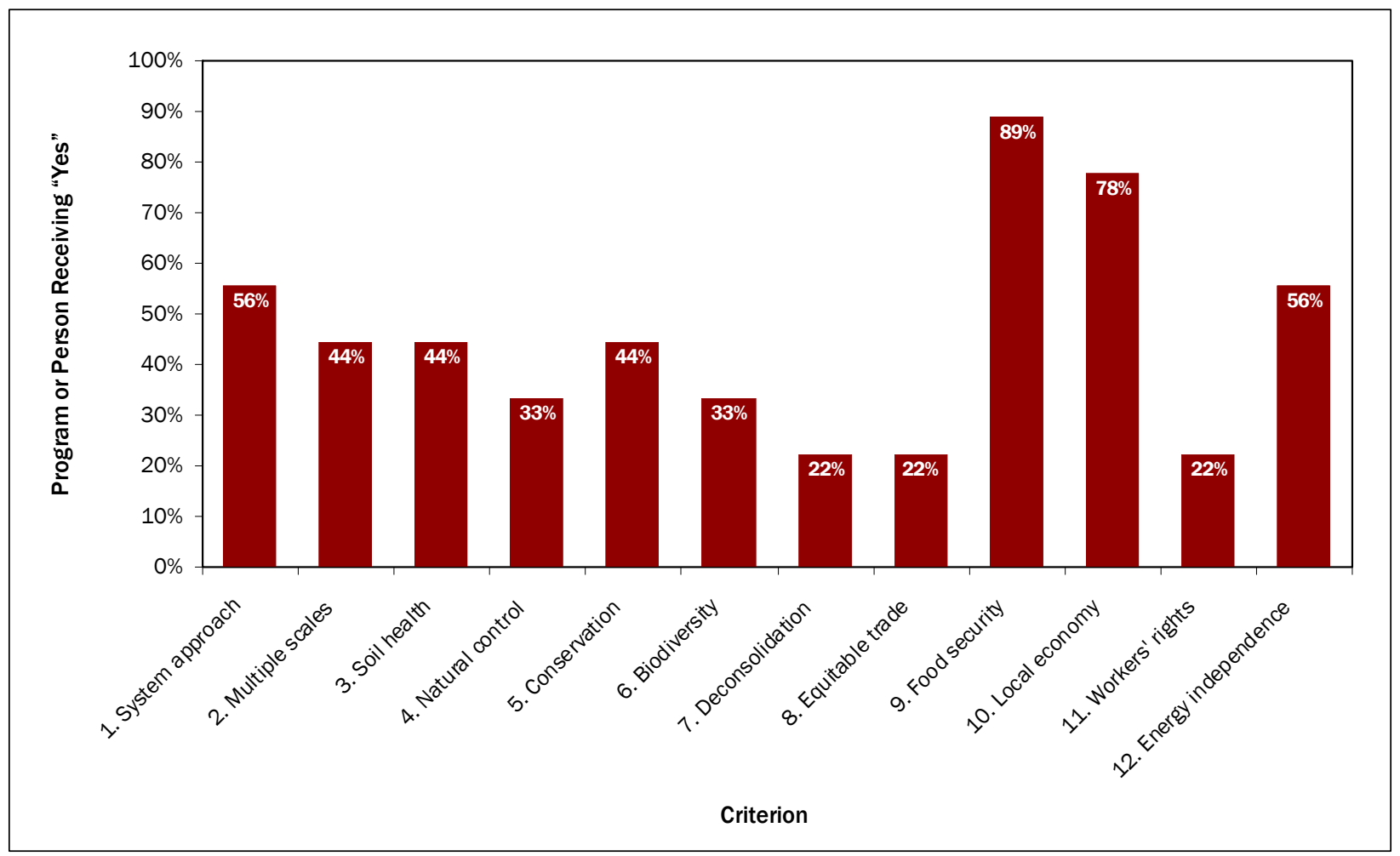

president's nomination of Beachy was grounded in the claim that Obama was not meeting the expectations he set as a candidate (PANNA, 2009).

\section{Discussion}

From our evaluation of these cases we are able to identify areas where the Obama administration has

focused some of its recent efforts and those that have received less attention (figure 1 and table 2 ). With programs such as HFFI, Let's Move!, and KYF2, which would increase access to cheap and healthy food, support small- and mid-scale farmers, and revive rural economies, the Obama administration is indicating a commitment to improving food security (criterion 9) and fostering local agrifood economies (criterion 10).

The administration's performance falls in the middle range for seven criteria (criteria 1-6 and 12). The number of programs and appointees receiving a "yes" for criteria 1 (systems approach) reflects the extent to which both agricultural production and social concerns linked to the food system are considered within particular administrative actions. The fact that the administration's performance on each of the "environmental soundness" criteria falls into the "moderate" category, despite the more social orientation of Obama's agriculture-related agenda (e.g., health care, childhood obesity, jobs creation), provides further evidence that the administration tends to consider social and environmental issues in connection to one another and is acting on a relatively holistic vision of the agrifood system that is more in line with the movement than those of previous administrations.

Finally, our results suggest that among the movement emphases, three have received less attention from this administration: corporate deconsolidation (criterion 7), equitable trade (criterion 8), and workers' rights (criterion 11). Within our evaluative framework, these criteria represent what are arguably the most transformational objectives of the alternative agrifood 


\begin{tabular}{|c|c|c|c|c|c|c|c|c|c|}
\hline & $\begin{array}{c}\text { Healthy } \\
\text { Food } \\
\text { Financing... }\end{array}$ & $\begin{array}{c}\text { Know } \\
\text { Your } \\
\text { Farmer... }\end{array}$ & $\begin{array}{l}\text { People's } \\
\text { Garden }\end{array}$ & Let's Move! & $\begin{array}{l}\text { Food } \\
\text { Environ- } \\
\text { mental } \\
\text { Atlas }\end{array}$ & $\begin{array}{l}\text { Kitchen } \\
\text { Garden }\end{array}$ & $\begin{array}{l}\text { Tom } \\
\text { Vilsack }\end{array}$ & $\begin{array}{l}\text { Roger } \\
\text { Beachy }\end{array}$ & $\begin{array}{l}\text { Kathleen } \\
\text { Merrigan }\end{array}$ \\
\hline \multicolumn{10}{|l|}{ Environmental Soundness } \\
\hline 1. System approach & No & Yes & Yes & No & No & Yes & Yes & No & Yes \\
\hline 2. Multiple physical scales & No & No & Yes & No & Yes & No & Yes & No & Yes \\
\hline $\begin{array}{l}\text { 3. Improvement of soil health, fertility, } \\
\text { biological activity }\end{array}$ & No & Yes & Yes & No & No & Yes & No & No & Yes \\
\hline 4. Natural control mechanisms & No & No & Yes & No & No & Yes & No & No & Yes \\
\hline 5. Resource conservation and maintenance & No & Yes & Yes & No & No & No & Yes & No & Yes \\
\hline $\begin{array}{l}\text { 6. Enhancement of biodiversity and } \\
\text { synergisms }\end{array}$ & No & No & Yes & No & No & Yes & No & No & Yes \\
\hline \multicolumn{10}{|l|}{ Social Critique } \\
\hline $\begin{array}{l}\text { 7. Deconsolidation of food production and } \\
\text { processing }\end{array}$ & No & Yes & No & No & No & No & No & No & Yes \\
\hline 8. Equitable trade & No & Yes & No & No & No & No & No & No & Yes \\
\hline $\begin{array}{l}\text { 9. Access to cheap, nutritious, and } \\
\text { appropriate food }\end{array}$ & Yes & Yes & Yes & Yes & Yes & Yes & Yes & No & Yes \\
\hline 10. Local agrifood economy & Yes & Yes & Yes & Yes & Yes & No & Yes & No & Yes \\
\hline 11. Farm and food system workers' rights & No & No & No & No & No & No & Yes & No & Yes \\
\hline 12. Energy independence & No & Yes & Yes & No & No & Yes & Yes & No & Yes \\
\hline
\end{tabular}

movement, and policies designed to advance these goals would require challenging politically powerful actors.

Consideration of the funding levels of the six policy actions we analyzed supports this analysis. Following the passage of the Healthy HungerFree Kids Act of 2010, Let's Move! is the most well funded of these cases by a substantial margin. If Congress approves funding at the levels proposed in earlier legislation, HFFI will be the only other case representing a multimillion dollar commitment. Both Let's Move! and HFFI address the same two criteria: They include provisions to improve food access and support the development of local agrifood economies.

Policy actions that address the environmental critique of the U.S. food system, as well as those that promote workers' rights, equitable trade, and deconsolidation - and would fundamentally challenge those who benefit from the current distribution of power in the food system - are 
small from a budgetary standpoint. Although the USDA's 2011 budget proposal includes US $\$ 2$ million to support KYF2, the initiative has no budget, office, or staff; according to Merrigan's office, the program is meant to support USDA staff in efforts to coordinate with each other and with stakeholders (USDA 2010a; Luke Knowles, phone interview, January 13, 2011). These policy actions may be symbolically powerful, but they are not being funded at the level of Let's Move! and HFFI, which are narrowly focused on food access and promote voluntary action by communities and the private sector to achieve it.

It is important to bear in mind that, with the exception of Let's Move!, funding for all six policy actions reviewed in this paper is minor compared to that allocated for major, ongoing federal programs in the area of food and agriculture. For example, the USDA's budget proposal for fiscal year 2011 allocates US $\$ 9$ billion for commodity programs, more than half of which is dedicated to direct payments to commodity producers (USDA, 2010d).

While it is not possible to compare the influence of appointees to the influence of policy actions using funding as a metric, it is important to consider both the relative influence of each of the appointees we reviewed and the ways their inclusion in the analysis impacts the outcomes. The professional record of the highest ranking appointee, USDA
Secretary Tom Vilsack, reflects attention to environmental and social issues emphasized by the alternative agrifood movement. Inclusion of his appointment as a case in our analysis strengthens the administration's performance on environmental criteria and three social criteria that are emphasized across the six policy actions (criteria 9, 10, and, to a lesser degree, 12), as well as one social criteria that received little attention in other initiatives: workers' rights. The other two appointees, Kathleen Merrigan and Roger Beachy, rank below Vilsack in the USDA hierarchy. It is therefore possible that their performance on particular criteria will inflate the administration's overall performance on those criteria out of proportion to the actual significance of their appointments. Merrigan's record is in line with movement priorities while Beachy's record is not, suggesting that the two appointments influence the overall results in opposing directions. However, given that NIFA is a department under the jurisdiction of one of seven undersecretaries of the USDA, whereas Merrigan oversees all seven, it is possible that our analysis overstates the significance of Beachy's influence. In this case, the performance of the administration against movement criteria would appear weaker than it would if the significance of the Beachy appointment were factored into our results.

Our analysis of the policy tools used by the six selected programs and initiatives reveals that the Obama administration relies primarily on what

Table 3. Funding, Policy Tools, and Criteria for Programs and Initiatives

\begin{tabular}{llllc}
\hline \multicolumn{1}{c}{ Program } & \multicolumn{1}{c}{ Funding } & \multicolumn{1}{c}{ Policy Tools Used } & $\begin{array}{c}\text { Environmental } \\
\text { Criteria Met }\end{array}$ & $\begin{array}{c}\text { Social } \\
\text { Criteria Met }\end{array}$ \\
\hline $\begin{array}{l}\text { Know Your Farmer, Know } \\
\text { Your Food }\end{array}$ & No dedicated budget & Capacity-building, Symbolic & 3 & 5 \\
\hline $\begin{array}{l}\text { Healthy Food Financing } \\
\text { Initiative }\end{array}$ & $\begin{array}{l}\$ 500 \text { million (approval } \\
\text { pending) }\end{array}$ & Incentive, Capacity-building & 0 & 2 \\
\hline $\begin{array}{l}\text { People's Garden Initiative } \\
\text { \$1 million plus }\end{array}$ & $\begin{array}{l}\text { Incentive, Capacity-building, } \\
\text { Symbolic }\end{array}$ & 6 & 3 \\
\hline Let's Move! & $\$ 4.5$ billion & $\begin{array}{l}\text { Incentive, Capacity-building, } \\
\text { Symbolic }\end{array}$ & 0 & 2 \\
\hline Food Environment Atlas & No dedicated budget & Capacity-building & 1 & 2 \\
\hline White House Garden & $\$ 200$ & Capacity-building, Symbolic & 4 & 2 \\
\hline
\end{tabular}


Schneider and Ingram (1990) refer to as capacitybuilding tools and symbolic and hortatory tools (table 3). All the programs and initiatives selected in this study use capacity-building tools to connect stakeholders with resources and information deemed important for them to contribute to changes in the agrifood economy. According to Schneider and Ingram (1990), capacity-building tools assume that the preferred policy alternatives will be chosen if people are informed and they have enough resources and support to carry them out. They also "operate on the assumption that the potential target populations will welcome the information and assistance" (Schneider \& Ingram, 1990, p. 519).

Symbolic and hortatory tools appeal to cultural beliefs and values in order to encourage people to take policy-related action (Schneider \& Ingram, 1990). Several of the programs and initiatives analyzed in this paper seek to change perceptions about food and agriculture by appealing to intangible values. Let's Move!, for example, links food and agriculture to children's health and the nationwide obesity epidemic. Similarly, the featuring of the White House Kitchen Garden on a popular television reality series and the catchy name of Merrigan's Know Your Farmer, Know Your Food initiative are examples of how the Obama administration is using persuasive communication techniques such as images, symbols, and labels to promote urban gardening and other activities aimed at reviving local agrifood economies. The use of symbolic and hortatory tools is a sign that the administration is attempting to create an image of alternative agrifood practices that fits within people's value schemes (Schneider \& Ingram, 1990). At the same time, Schneider and Ingram (1990) warn that symbolic and hortatory tools may "seek to convince people of the importance and priority government is associating with certain activities and goals, even though actual commitment of resources or development of programs may not be underway" (p. 520).

Three out of six of the programs and initiatives we analyzed also mobilize incentive tools to promote some of the practices championed by the alterna- tive agrifood movement. HFFI uses positive tangible pay-offs such as loans, loan guarantees, grants, and tax credits to encourage private and nonprofit initiatives that bring food retail outlets to areas where they are currently scarce. The incentive tools in Let's Move! and the People's Garden Initiative are small components of the overall programs. While the use of incentive tools indicates that the Obama administration is backing its commitment to an alternative agrifood system with resources, the selected case studies also point out that, in terms of incentive tools, the administration is relying primarily on weak positive rewards to influence action.

Our case-studies analysis also reveals that the Obama administration is not mobilizing authority tools and learning tools to supplement its commitment to promote alternative agrifood practices. While the administration is making creative use of new media such as blog spaces to reach out to the general public, it fails to include formal channels through which it can assess public opinions and needs in order to shape selected programs and initiatives.

The Obama administration has advanced regulatory and authority tools through its support and initiation of a few key pieces of legislation. The US $\$ 4.5$ billion Healthy, Hunger-Free Kids Act of 2010 aims to improve the quality of school meals and "play an integral role in our efforts to combat childhood obesity," according to Mrs. Obama (Kohan, 2010b, "US House Passes Historic," para. 5). This legislation is the central policy component of the first lady's Let's Move! campaign. In December 2010, the president reaffirmed his administration's commitment to addressing institutionalized discrimination in agriculture by signing the Claims Resolution Act of 2010 to disburse funds that had been won by Black farmers and Native Americans through settlements in suits against the federal government (commonly referred to as the Pigford case). Obama first introduced legislation for this purpose during his term in the Senate (Kohan, 2010c). President Obama has also been an outspoken advocate for the passage of the FDA Food Safety Modernization Act (Murphy, 
2010). This bill received support from the alternative agrifood movement after exemptions to certain safety and reporting requirements were made for small farmers making under US $\$ 500,000$ a year (Lebens, 2010). All three of these laws mandate action by public institutions and private companies. Administrative advocacy in these legislative initiatives may demonstrate a commitment to using strategies not found within our analysis. These pieces of legislation address equitable trade, food security and safety, and food system worker rights (criteria 8, 9, and 11), which have been foci of alternative agrifood organizing.

Finally, our analysis suggests that the exchange between the Obama administration and the alternative agrifood movement is multidirectional. Kathleen Merrigan's appointment and the White House Kitchen Garden were both specifically requested by the movement and the many online supporters who signed the petitions delivered to the president. The Healthy Food Financing Initiative (HFFI) is modeled after a program developed in Pennsylvania in 2004, the Pennsylvania Fresh Food Financing Initiative (FFFI). On the other hand, the alternative agrifood movement has clearly expressed its disappointment with some of the stances of the new administration on food and agriculture (e.g., the appointments of Tom Vilsack and Roger Beachy). Whether the movement will soften its demands of the administration because of perceived successes remains to be seen, and this possibility should be assessed as Obama's presidency progresses.

\section{Conclusions}

Our analysis of six selected initiatives and programs reveals that the Obama administration is using predominantly incentive, capacity-building, and symbolic tools to foster changes in the U.S. agrifood system. This is in line with what Salamon (2002) describes as the massive proliferation of tools of public action that increasingly include third parties. According to Salamon, third-party governance has become increasingly popular since the 1950s specifically because it relies on indirect tools of public action that involve third-party actors such as commercial banks and universities. Indirect tools allow the government to tap into talents and resources that public agencies may not have. At the same time, they give rise to challenges in the management and accountability of these dispersed semiautonomous entities and erode government legitimacy.

The tools used by the administration can also be described as emblematic of regulatory reform in the political processes of "roll-out neoliberalization" as described by Peck and Tickell (2002). In the United States a phase of roll-back neoliberalism led to the dismantling and defunding of programs of the welfare state. More recently, the processes of roll-out neoliberalization have created new modes of governance that both empower the market as authority and assert the power of the state. Tools used in these processes of re-regulation include the devolution of responsibility and resources to local administrations, partnerships with private-sector and third-party organizations in policy development and program delivery, the use of social capital discourses and tools, the mobilization of volunteers to take responsibility for issues once covered by the state, and greater emphasis on personal responsibility (Peck \& Tickell, 2002). In food and agriculture scholars have observed both responsibilization (i.e., the delegation of government responsibility to community actors for providing basic food needs, pesticide protection, etc.) and valuation (e.g., the privatization of seed resources and reliance on market strategies such as farmers' markets and entrepreneurial efforts) (Guthman, 2008). The Obama administration's reliance on capacity-building, incentives, and symbolic acts intended to inspire action clearly reflect an emphasis on responsibilization.

The tools that the Obama administration has chosen to carry out programs aimed at transforming the agrifood system influence the set of strategies nongovernmental actors may suggest to bring about systematic change. Our analysis also indicates that the alternative agrifood movement has actively influenced administrative actions. We observed that several of the administration initiatives came directly from calls or suggestions from the alternative agrifood movement. The movement 
has focused largely on creating alternatives at the margins of the dominant agrifood system (Allen, 2004). Guthman (2008) observes that these alternatives reflect four central themes: consumer choice and the power of the consumer, localism, entrepreneurialism, and food and farming as a means of self-improvement. These themes echo neoliberal rationales that include the power of the market as a governing structure and the devolution of responsibilities to local communities and the individual (Guthman, 2008).

However, agrifood activists have not relied exclusively on strategies that align with roll-out neoliberalism; they also have lobbied government to strengthen food entitlement programs (such as SNAP and WIC), improve government-funded school meals, address food safety, and address issues of justice in USDA programs. It is important to note that the Obama administration has taken action on several of the above concerns through its support and initiation of the Healthy, Hunger-Free Kids Act, the Claims Resolution Act, and the FDA Food Safety Modernization Act.

The behavioral assumptions of the tools used by the Obama administration reflect not only the political-economic trends of this neoliberal era, but also the demands of alternative agrifood activism. A dialogic relationship between movement and administration coproduces the set of strategies deployed in both policy and activism. Allen (2010) suggests that many actors in alternative agrifood movements choose their strategies not out of ignorance to injustices in political and economic structures, but out of desire to make a difference in the here and now. The strategies and themes chosen by a movement work not only to create change in the present, but also point the direction for future change by shaping the ideas and conceptualizations of possibilities of its participants (Guthman, 2008). Analysis of movement goals and strategy is clearly needed to effectuate the desired change in current conditions while building toward an equally desired future.

Time is needed to observe this relationship and the direction of change in the national food system. At this time we are unable to analyze any of the outcomes of Obama's programs and appointments and compare them to their objectives or the movement's critique of conventional agriculture. A similar analysis repeated at the end of Obama's term would allow for an outcomes-based analysis, which in turn would contribute greatly to our understanding of how the relationship between the alternative agrifood movement and the Obama administration has evolved through time, and whether it has produced any measurable changes.

\section{Acknowledgements}

The authors wish to acknowledge the Agro-Food Studies Research Group at the University of California, Santa Cruz, especially Margaret Fitzsimmons, for valuable comments on an earlier draft of this paper. The project was developed in a graduate seminar in Environmental Studies and benefited from the guidance and suggestions from the instructors of that seminar, Weixin Cheng and Tim Duane, as well as from discussion with classmates Heather Briggs, Sharifa Gulamhussein, Lewis Reed, Catherine Wade, Tiffany Wise-West, and Veronica Yovovich. Leah Samberg also provided helpful feedback. We would also like to thank Mateo deeply for getting the ball rolling early and swiftly on our research.

\section{References}

Aldhous, P. (2009, October 8). Roger Beachy: GM crop pioneer now US farm science chief. New Scientist. Retrieved from http://www.newscientist.com/ article/dn17945-roger-beachy-gm-crop-pioneernow-us-farm-science-chief.html

Allen, P. (2004). Together at the table: Sustainability and sustenance in the American agrifood system. University Park, PA: Pennsylvania State University.

Allen, P. (2010). Realizing justice in local food systems. Cambridge Journal of Regions, Economy and Society, 3(2), 295-308.

AllGov. (2009). Tom Vilsack profile. Retrieved from http://www.allgov.com/Official/Vilsack Tom

Altieri, M. (2002). Agroecology: The science of natural resource management for poor farmers in marginal environments. Agriculture, Ecosystems and Environment, 93, 1-24. doi:10.1016/S0167-8809(02)00085-3

Associated Press. (1985, September 12). Congress ponders extent of farm debt crisis. The New York 
Times. Section D. Retrieved from http://proquest. umi.com $/$ pqdweb? $\mathrm{did}=954194561 \& \mathrm{sid}=4 \& \mathrm{Fmt}=3$ $\underline{\text { \&clientId }=1565 \& \mathrm{RQT}=309 \& \mathrm{VName}=\mathrm{PQD}}$

Associated Press. (2010, January 12). White House garden "ex-seeds" expectations. MSN Today. Retrieved from http://today.msnbc.msn.com/ id/34820763/ns/today-today people/

Beachy, R. N. (1999, July 16). Facing fear of biotechnology [Editorial]. Science, 285(5426), 335. doi:10.1126/science. 285.5426 .335

Beachy, R. N. (2006). Field work. Crop Science, 46, S-2. doi:10.2135/cropsci2006.0003tpg

Black, J. (2009a, February 5). Vilsack: USDA must serve eaters as well as farmers. The Washington Post. Retrieved from http://www.washingtonpost. com/wp-dyn/content/article/2009/02/04/ AR2009020403467.html

Black, J. (2009b, March 25). Where policy grows: Iowan Dave Murphy is challenging the corporate farming of America. The Washington Post. Retrieved from http://www.washingtonpost.com/wp-dyn/ content/article/2009/03/24/AR2009032400754. $\underline{\mathrm{html}}$

Brown, L. (2010, February 9). US\$400M Healthy Food Financing Initiative proposed in presidential budget. Earth911.com. Retrieved from http://earth911.com/news/2010/02/09/400mhealthy-food-financing-initiative-proposed-inpresidential-budget/

Burros, M. (2009, March 19). Obamas to plant vegetable garden at White House. The New York Times. Retrieved from http://www.nytimes.com/2009/ 03/20/dining/20garden.html

Community Food Security Coalition. (2010a, February 3). Memo to CFSC members on CFSC priorities in the Obama Administration's FY 2011 budget proposal. Retrieved from http://www.foodsecurity. org/policy/Presidents FY2011 Budget ProposalMemo To CFSC Members.pdf

Community Food Security Coalition. (2010b, February 23). Action update for Farm to School in the CNR. Retrieved from http://www.foodsecurity.org/ policy/F2S CNR Action 2-23-10.pdf

Constance, D. H. (2009). The four questions in agrifood studies: A view from the bus. Agriculture and Human Values, 26, 3-14. doi:10.1007/s10460-008-9187-0

Cummins, R. (2008, December 17). OCA: Vilsack not "change we can believe in" [Organic Consumers Association press release]. Retrieved from http://www.organicconsumers.org/articles/ article $16156 . \mathrm{cfm}$
DeForest, A. (2010, January 27). A national push to make healthy food available to all. Urban Farm Hub. Retrieved from http://www.urbanfarmhub. org/2010/01/a-national-push-to-make-healthyfood-available-to-all/

Doiron, R. (2010). White House Kitchen Garden Campaign. Retrieved from http://kitchengardeners. org/white-house-kitchen-garden-campaign

Donald Danforth Plant Science Center. (2010). Roger Beachy. Retrieved from http://www. danforthcenter.org/science/laboratories/ Roger Beachy/

Endelman, R. (2009, October 29). Islam Siddiqui and Roger Beachy - suitable public servants? [The Delicious Truth blog post]. Retrieved from http://thedelicioustruth.blogspot.com/2009/10/ islam-siddiqui-and-roger-beachy.html

Estabrook, B. (2009, September 17). Politics of the plate: Talking the talk on sustainable food. Gourmet. Retrieved from http://www.gourmet.com/ foodpolitics/2009/09/obama-sustainable-foodfarm-bill

Farmers Market Coalition. (2010, February 16). Using the USDA's new U.S. Food Environment Atlas: Opportunities for farmers market supporters. Retrieved from http://farmersmarketcoalition. org/foodatlas/

Ferguson, E. (2010, October 25). Vilsack's mission: Transform rural America. CQ Weekly Online, 24232425.

Gliessman, S. R. (n.d.) An ecological definition of sustainable agriculture. http://agroecology.org/Principles Def.html

Goodman, J. (2008, October 10). McCain and Obama need to talk real farm policy. CommonDreams.org. Retrieved from http://www.commondreams.org/ view $/ 2008 / 10 / 10-3$

Guthman, J. (2008). Neoliberalism and the making of food politics in California. Geoforum, 39, 1171-1183. doi:10.1016/i.geoforum.2006.09.002

Hansen, B. (2003, May 9). Crisis on the plains: Can dying rural communities be saved? CQ Researcher, 13(18), 417-448.

Hassanein, N. (2003, January). Practicing food democracy: A pragmatic politics of transformation. Journal of Rural Studies, 19(1), 77-86. doi:10.1016/S0743-0167(02)00041-4

Heffernan, W., Hendrickson, M., \& Gronski, R. (1999, February 5). Consolidation in the food and agriculture system. Report to the National Farmers Union. Available at http://www.nfu.org/mediagalleries/document-library/heffernan-report/ 
Jenkins, G. (2009). USDA unveils "Know Your Farmer, Know Your Food" initiative. Slow Food USA. Retrieved from http://www.slowfoodusa.org/ index.php/slow food/blog post/usda unveils kn ow_your_farmer_know_your_food_initiative/

Johnson, R. (2010, February 17). Uproot: Playing with the new Food Environment Atlas. San Francisco Bay Guardian Online. Retrieved from http://www.sfbg. com/pixel vision/2010/02/17/uproot-playingnew-food-environment-atlas

Kass, S. (2010, April 2). Spring planting [The White House Blog post]. Retrieved from http://www.whitehouse.gov/blog/2010/04/02/ spring-planting-white-house-kitchen-garden

Klein, J. (2008, October 23). The full Obama interview [Swampland blog post]. Retrieved from http://swampland.blogs.time.com/2008/10/23/ the full obama interview/

Kline, D. (1981, November 29). The embattled independent farmer. New York Times Magazine. Retrieved from http://www.nytimes.com/ $1981 / 11 / 29 /$ magazine/the-embattledindependent-farmer.html

Kohan, E. G. (2009a, September 15). Know Your Farmer, Know Your Food...know your tactical team. USDA announces big plans and US $\$ 50$ million for local school lunches [Obama Foodorama blog post]. Retrieved from http://obamafoodorama.blogspot.com/2009/09/ know-your-farmer-know-your-foodknow $15 . \mathrm{html}$

Kohan, E. G. (2009b, April 17). The People's Garden at USDA: From green fever dream to rapid reality [Obama Foodorama blog post]. Retrieved from http://obamafoodorama.blogspot.com/2009/04/ peoples-garden-at-usda-from-green-dream.html

Kohan, E. G. (2010a, February 9). Mapping food access for Let's Move: USDA launches the Food Environment Atlas [Obama Foodorama blog post]. Retrieved from http://obamafoodorama.blogspot. com/2010/02/mapping-food-access-for-lets-moveusda.html

Kohan, E. G. (2010b, December 2). US House passes historic child nutrition bill championed by first lady Michelle Obama [Obama Foodorama blog post]. Retrieved from http://obamafoodorama.blogspot. $\underline{\mathrm{com} / 2010 / 12 / \text { house-passes-first-lady-michelle- }}$ obamas.html

Kohan, E. G. (2010c, December 8). President signs Claims Resolution Act of 2010 [Obama Foodorama blog post]. Retrieved from http://obamafoodorama.blogspot.com/2010/12/ president-obama-signs-claims-settlement.html
Layzer, J. A. (2008). Natural experiments: Ecosystem-based management and the environment. Cambridge: Massachusetts Institute of Technology.

Lebens, N. (2010, December 22). Food safety bill passes with exemption for small farms. Minnesota Public Radio. Retrieved from http://minnesota. publicradio.org/collections/special/columns/ ground-level/archive/2010/12/food-safety-withan-exemption-for-small-farms.shtml

Lee, J. (2009, March 20). Spring gardening [The White House Blog post]. http://www.whitehouse.gov/ blog/09/03/20/spring-gardening/

Lockeretz, W., \& Merrigan, K. (2006). Ensuring comprehensive organic livestock standards. In Proceedings of the 1st IFO AM International Conference on Animals in Organic Production. Reference retrieved from http://www.reeis.usda.gov/web/crisprojectpages/ 201444.html

Lohan, T. (2010, February 20). A food atlas like you've never seen [Change.org blog post]. http://news.change.org/stories/a-food-atlas-likeyouve-never-seen

Marlowe, B. (2010). Kathleen Merrigan. WhoRunsGov. Washington, DC: Washington Post Company. Retrieved from http://www.whorunsgov.com/ Profiles/Kathleen Merrigan

McCarvel, B., \& Braun, J. (2009, March 26). Letter to first lady Michelle Obama on behalf of the Mid American CropLife Association. Retrieved from http://www.croplife.com/news/?storyid $=1657$

Merrigan, K. (2005). Organic food regulations: Part art, part science. In C. Hassler (Ed.), Regulation of functional foods and nutraceuticals: A global perspective, (pp. 69-78). Ames, Iowa: Blackwell Press. doi:10.1002/9780470277676.ch4

Merrigan, K., \& Bailey, M. (2008). The potential of farm-to-college programs. Nutrition Today, 43(4), 160-165. doi:10.1097/01.NT.0000303339.75605.9e

Muir, D., \& Wright, S. (2009, January 9). White House chef meets "Iron Chef' challenge. $A B C$ News. Retrieved from http://abcnews.go.com/Politics/ white-house-chef-meets-iron-chef-challenge/ story?id $=9521467$

Murphy, E. (2010, December 4). Food safety bill passes Senate but stymies ability to clear House [FDA Lawyers Blog post]. Retrieved from http://www.fdalawyersblog.com/2010/12/foodsafety-bill-passes-senate.html

National Sustainable Agriculture Coalition. (2009, February 23). Sustainable farming group applauds choice of Merrigan as USDA Deputy Secretary 
[Press release]. Retrieved from http://sustainable agriculture.net/press/archived-press-releases/

National Sustainable Agriculture Coalition. (2010a, February 9). Let's move to beat childhood obesity [blog post]. Retrieved from http://sustainable agriculture.net/blog/lets-move-to-beat-childhoodobesity

National Sustainable Agriculture Coalition. (2010b, February 19). Peterson and Vilsack endorse local and regional food at Home Grown [blog post]. http://sustainableagriculture.net/blog/homegrow/

O'Connor, K., Nye, B., \& van Assendelft, L. (1996). Wives in the White House: The political influence of first ladies. Presidential Studies Quarterly, 26(3), 835-853.

Obama, M. (2010, February 9). Remarks prepared for delivery of Let's Move! launch, Washington, DC.

Obama for America. (2008). Barack Obama and Joe Biden: Promoting a healthy environment. Retrieved from http://www.barackobama.com/pdf/issues/ EnvironmentFactSheet.pdf

Office of the First Lady. (2009, April 9). White House Kitchen Garden fact sheet. Retrieved from http://www.whitehouse.gov/the press office/ FLOTUS-remarks-from-garden-planting-event

Organic Consumers Association. (2008, November 8). Good news of the week: Happy regime change. Organic Bytes [blog post], issue150. Retrieved from http://www.organicconsumers.org/bytes/ ob150post.htm

Organizing for America. (2008). Plan to support rural communities. Retrieved from http://www.barack obama.com/issues/rural/index_campaign.php

Orton, B. (2009, February 25). "Secretary of Agrispinculture" Vilsack dedicates fake "People's Garden." Retrieved from http://www.waxing america.com/2009/02/secretary-of-agrispinculturevilsack-dedicates-fake-peoples-garden.html

Peck, J., \& Tickell, A. (2002). Neoliberalizing space. Antipode, 34(3), 380-404. doi:10.1111/1467-8330.00247

Pesticide Action Network North America (PANNA). (2009). Monsanto and CropLife men have no place in government. Retrieved from http://action. panna. org/t/5185/petition.jsp?petition $\underline{K E Y=2150}$

Petrini, C., \& Lionette, J. (2007). Manifestos on the future of food and seed. New York: South End Press.

PolicyLink. (2010a). Improving access to healthy food. Retrieved from http://www.policylink.org/ site/c.lkIXLbMNJrE/b.5136687/k.61DA/ Healthy Food Retailing.htm
PolicyLink. (2010b). Obama's budget funds national Healthy Food Financing Initiative. Retrieved from http://www.policylink.org/site/apps/nlnet/ content2.aspx? $\mathrm{b}=5156723 \& \mathrm{c}=1 \mathrm{kIXLbMNJ}$ rE\&ct $=7976291$

Pollan, M. (2008, October 12). Farmer in chief. The New York Times Magazine, p. MM62.

Project Vote Smart. (2008). Energy and Environmental Record. Unattributed speech introducing Vilsack during his 2008 presidential campaign. Retrieved from http://www.votesmart.org/speech detail.php?sc id $=269141 \&$ keyword $=\&$ phrase E\&contain $=$

Reinvestment Fund, The. (2007, December). Pennsylvania Fresh Food Financing Initiative: Providing healthy food choices to Pennsylvania's communities. Retrieved from http://www.thefood trust.org/pdf/FFFI\%20Brief.pdf

Richardson, J. (2009, September 25). One week, two bad appointments, Monsanto throws party. La Vida Locavore [blog post]. Retrieved from http://www. lavidalocavore.org $/$ showDiary.do?diaryId $=2532$

Salamon, L. M. (2002). The new governance and the tools of public action: An introduction. In L. M. Salamon (Ed.), The tools of government: A guide to the new governance (pp. 1-47). New York: Oxford University Press.

Schneider, A., \& Ingram, H. (1990). Behavioral assumptions of policy tools. Journal of Politics, 52(2), 510-529. doi:10.2307/2131904

Scott, A. (1990). Ideology and the new social movements. London: Unwin Hyman.

Shames, L. (2009, April 24). Agricultural concentration and agricultural commodity and retail food prices [Briefing for Congressional staff]. Washington, DC: United States Government Accountability Office.

Stockwell, S. (2010, February 13). Re: Let's Move to Beat Childhood Obesity [National Sustainable Agriculture Coalition blog comment]. Retrieved from http://sustainableagriculture.net/blog/ lets-move-to-beat-childhood-obesity/

Stokstad, E. (2011, April 29). Beachy to leave key agriculture research post in Washington. ScienceInsider. http://news.sciencemag.org/ scienceinsider/2011/04/beachy-to-leave-keyagriculture.html?ref $=\mathrm{hp}$

Taylor, S. (2009, April 23). Michelle's green garden upsets pesticide makers. The First Post [blog post]. Retrieved from http://www.thefirstpost.co.uk/ 47131,people,news, michellersquos-green-gardenupsets-pesticide-makers?lost $=1$ 
Thompson, K. (2010, February 16). Q \& A with Agriculture Secretary Tom Vilsack. The Washington Post. Retrieved from www.washingtonpost.com/

U.S. Congress. (2010a, December 13). Healthy, HungerFree Kids Act of 2010. Public Law No: 111-296. 124 U.S. Statutes at Large, 3183.

U.S. Congress. (2010b, November 30). House. The Healthy Food Financing Initiative. HR 6462. 111th Cong., 2nd sess. Congressional Record 156, H 7757.

U.S. Congress. (2010c, November 30). Senate. The Healthy Food Financing Initiative. S 3986. 111th Cong., 2nd sess. Congressional Record 156, S 8298.

U.S. Department of Agriculture (USDA). (2009a). Agriculture Deputy Secretary Merrigan launches website for "Know Your Farmer, Know Your Food"; plans Facebook chat to expand conversation on local food systems. Release No. 0465.09. Retrieved from http://www.usda.gov/ wps/portal/usdahome? contentidonly $=$ true \&contentid $=2009 / 09 / 0465 . x \mathrm{ml}$

U.S. Department of Agriculture (USDA). (2009b, December 15). Agriculture Secretary Vilsack discusses how Obama administration is partnering with farmers and ranchers to combat climate change. Release No. 0612.09. Retrieved from http://www.usda.gov/wps/portal/usda/!ut/p/c5/ 04 SB8K8 xLLM9MSSzPy8xBz9CP0os gAC9-wM [8QY0MDpxBDA09nXw9DFxcXQ-cAA 1wkA 5kFaGuQBXeASbmnu4uBgbe5h B5AxzA0UD fzyM N1W IDs7zdFRUREAZXAypA!!/dl3/d3/ L2dJQSEvUUt3QS9ZQnZ3LzZfUDhNVIZMVD MxMEJUMTBJQ01IMURERDFDUDA!/?content idonly $=$ true $\&$ contentid $=2009 \% 2 \mathrm{f} 12 \% 2 \mathrm{f} 0612 . \mathrm{xml}$

U.S. Department of Agriculture (USDA). (2010a, July 14). Agriculture Secretary Vilsack launches showcase on "Know Your Farmer, Know Your Food” website. Release No. 0368.10.

U.S. Department of Agriculture. (2010b). About the Food Environment Atlas, "Objectives of the Atlas," Retrieved from http://ers.usda.gov/ foodatlas/about.htm

U.S. Department of Agriculture (USDA). (2010c, February 9). First Lady Michelle Obama launches Let's Move: America's move to raise a healthier generation of kids [Release No. 0058.10]. Retrieved from http://www.usda.gov/wps/portal/usda/!ut/ $\mathrm{p} / \mathrm{c} 4 / 04$ SB8K8xLLM9MSSzPy8xBz9CP0os gAC 9-wMJ8QY0MDpxBDA09nXw9DFxcXw2ALU 2CbEdFAF-soRU!/?printable $=$ true\&contentid only $=$ true $\&$ contentid $=2010 \% 2 \mathrm{~F} 02 \% 2 \mathrm{~F} 0058 . \mathrm{xml}$
U.S. Department of Agriculture (USDA). (2010d). FY 2011 budget summary and performance plan. Retrieved from http://www.obpa.usda.gov/ budsum/FY11budsum.pdf

U.S. Department of Agriculture (USDA). (2010e, February 19). Obama administration details Healthy Food Financing Initiative. Release No. 0077.10. Retrieved from http://www.usda.gov/wps/ portal/!ut/p/ s.7 0 A/7 0 1OB? contentidonly= true\&contentid $=2010 / 02 / 0077 . \mathrm{xml}$

U.S. Department of Health and Human Services. (2010, February 19). Obama administration details Healthy Food Financing Initiative. Retrieved from http://www.hhs.gov/news/press/2010pres/02/20 100219a.html

U.S. Working Group on the Food Crisis. (2008, December 15). Open Letter to President Elect. Retrieved from http://www.foodfirst.org/en/ node/2331

Vig, N. J. (2010). Presidential powers and environmental policy. In N. J. Vig \& M. E. Kraft (Eds.). Environmental policy: New directions for the twenty-first century (pp. 75-98). Washington, DC: CQ Press.

Waltz, E. (2010). Roger Beachy. Nature Biotechnology, 28(1), 11-12. doi:10.1038/nbt0110-11

Warner, K. (2007). Agroecology in action: Extending alternative agriculture through social networks. Cambridge: Massachusetts Institute of Technology.

Wezel, A., \& Soldat, V. (2009). A quantitative and qualitative historical analysis of the scientific discipline of agroecology. International Journal of Agricultural Sustainability, 7(1), 3-18. doi:10.3763/ijas.2009.0400

Witteman, A. (2010, February 1). Obama budget snapshot of sustainable agriculture [National Sustainable Agriculture Coalition blog comment]. Retrieved from http://sustainableagriculture. net/blog/obama-budget-snapshot-of-sustainableagriculture 